\title{
chaper Sexual Diversity and UK Psychiatry and Mental Health
}

\author{
Annie Bartlett
}

\section{Introduction}

While the stories of sexual diversity did not begin in 1960 there is no doubt that the fifty years that followed saw radical changes in thinking about sex, gender and sexual practice. To be alive now is to live in interesting times, ones in which new categories of meaning about sexuality and gender are proliferating. These provide individuals with innovative ways of explaining themselves to each other and to themselves. That idea of self-definition, rather than definition by experts, including psychiatrists, is a key shift; much of that movement happened between 1960 and 2010. This was a period in which UK psychiatry was part of the wider debate about gender and sexuality but also a period where its contribution to the evolution of thinking about sexual diversity and its capacity to provide appropriate services to sexual minorities came under considerable scrutiny.

The premise of the chapter is that what happened within UK psychiatry and mental health did not do so in a social vacuum. So it documents key changes, judged in terms of what does or does not and should not constitute a mental disorder as well as corresponding amendments to legal rights and restrictions, as they relate to different genders, sexual identities and practices. Yet that is only part of the story. Psychiatry between 1960 and 2010 has been practised largely within the NHS with a smaller number of mental health practitioners operating psychiatric or psychological services either privately or within voluntary sector groups. Practitioner views are important in shaping care and they have not been static. Equally, both research and practice over this period of time have led to a broader understanding of the mental health issues encountered by individuals from sexual minorities and to a prevailing view that many of these difficulties stem from the negative responses of the wider community (including family and school) rather than being intrinsic to the minority identity. Research has, perforce evolved, so that it has investigated the nature and frequency of mental health problems within what is now, but was not earlier, the LBGTQI community. This new focus could be characterised as a move from being the problem to having problems. This forms a local, UK-centred, backdrop to the patchwork quilt information on the experiences of those accessing services for mental health difficulties, be that voluntarily or involuntarily, be they statutory services or from voluntary sector or private providers.

This contribution is limited in scope but necessarily draws on work describing events in other countries but known to those of us living and working in the UK. Social historians in the UK have set the wider scene in which the changes described here occurred and it would be absurd not to acknowledge the relationships between psychiatry, liberalisation in public attitudes, campaigning, legislative change and the ongoing internal conflicts within major 
religions on their position in relation to sexual minorities. The presumption here is that these do relate to the overall impetus within psychiatry to keep abreast of changing thinking rather than to direct it.

Nor are these essentially social debates confined to single jurisdictions. The social situation of sexual minorities varies in the West and internationally. In July 2020, Poland reelected a president opposed to gay rights. There are a number of countries in the world with records of state violence against gays, some with legislation that allows for the death penalty for consensual same-sex sexual expression between adults. The Royal College of Psychiatrists has members from all over the globe and this issue continues to challenge it even as the UK basks within a socially liberal atmosphere, albeit one that is only recently acquired. The delicacy of the position of the College is that it risks a neocolonialist position when speaking to an international audience, in which old tropes about the hegemony of Western-inspired categories of meaning can be dusted off. At the same time, as the rest of the world dances to its own tunes, ${ }^{1}$ indigenous concepts of gender identity and sexual expression can be and are reworked for modern times by those for whom such identities are their life, often drawing on historical models of multiple genders. ${ }^{2}$

Writing about sexual diversity in earlier decades could incur the wrath of the censors. ${ }^{3}$ This remains the case. The judgements of the next generation on today's thinkers may be unkind. The previously radical figure Germaine Greer and, more recently, the internationally renowned author J. K. Rowling have found out that, regardless of their intent, it is easy to invoke opprobrium. ${ }^{4}$ This chapter will attempt to tread carefully, speaking about, not for, but it enters a hot debate, most obviously today in relation to transgender politics and health care.

\section{Sexual Diversity: Concepts, Categories and Contemporary Currency}

Underpinning this discussion is the tricky issue of categories. What constitutes sexual diversity has long been contested. Central to this chapter is the balance of power between those who have been heavily pathologised by prevailing psychiatric concepts and the institution of psychiatry and its practitioners. The real story of the last sixty years is the reclaiming of autonomy and the move to self-definition by those of us who do not find ourselves sitting comfortably in a heteronormative, gender binary culture. What has not changed is the penchant, indeed enthusiasm, for categories. Sexual diversity continues to provide many conceptual categories, functioning as coat hangers on which individuals can hang their own experience of themselves, or not.

In the 1960s, the main focus in the UK was homosexuality, to use the term of the day. The Wolfenden Committee had reported on homosexuality (and prostitution, strange bedfellows from the perspective of 2020) in 1957..$^{5}$ The history of the word 'homosexuality' is instructive. Weeks argues that it was only one of a number of terms emerging in the late nineteenth century as writing on sexual preference emerged from private diaries into a public spotlight. ${ }^{6}$ Despite its centrality to Wolfenden, he suggests it was not owned by those who saw themselves as 'queer'. Lesbianism and Sapphism had an obvious connection to the island of Lesbos and the poetry of Sappho, invoking a notionally golden past of communities of women with same-sex desires. These terms were superseded in time in part by the word 'gay', a word adopted by both men and women but which has never entirely replaced the word 'lesbian'. Medical discourse on same-sex sexuality stuck firmly to 
homosexuality, often ignoring women. ${ }^{7}$ The British Journal of Psychiatry currently contains 127 papers on homosexuality, 17 on lesbians and a rather confusing 35 thrown up by 'gay' in the search engine, many of the latter being nothing to do with sexuality.

The messy history of vocabulary, where words have currency in different and overlapping social arenas, says much about what happened as political activism, both male and female, took private struggles to a visible, political front line. Events such as the Stonewall riots in 1969 and the abseiling of women into a TV studio to protest against Section 28 of the Local Government Act 1988, derived and owed much to a motley crew of local and national groups campaigning and creating safer social spaces for what was increasingly, but not necessarily accurately, called a community. ${ }^{8}$ Derogatory terms, or words that indicated some degree of self-loathing, such as 'dyke' or 'poof', became at least contested and in part reclaimed as the voice of the 'community' grew louder and more confident. While explicitly gay organisations, such as Gay Liberation Front (GLF), did much to support the daily life of often isolated gays and lesbians, this was more true for men than women who also found a home in the women's movement. There, concepts such as lesbian feminism and compulsory heterosexuality were debated alongside lesbian motherhood, men's use of pornography and other aspects of the patriarchy. ${ }^{9}$

The arrival of AIDS in the early 1980s both contributed to this public identification of an emerging gay community and vilified gay men. It can be understood, however, as a turning point, not only for AIDS but also for medicine as demands to be involved in treatment trials in a different way paved the way for greater patient involvement in care and research. ${ }^{10}$ An era of sexual experimentation and hedonism turned to personal tragedy for many and this sobering experience also highlighted the absence of basic rights within gay relationships.

It is salutary to note that the voice of bisexual and transgender people was noticeably absent for much of this period. The pioneering academic work of Charlotte Wolff is one of few attempts to document the experiences of bisexuals at that time. ${ }^{11}$ The subjectivity of trans individuals was publicly aired intermittently or privately rehearsed over decades. ${ }^{12}$ It is only in the twenty-first century, partly assisted by campaigning organisations such as Stonewall and Mermaids, ${ }^{13}$ that trans issues have come to the fore really. The cinderellas of sexual minority activism have perhaps had their territory invaded by the plethora of new subjectivities emerging which challenge conventional understandings of both gender and sexuality. Non-binary, gender queer, gender fluid and third gender contest the concept of binary gender and themselves may or may not sit under a transgender umbrella, all with a range of sexual expressions. This is happening now and will in time generate its own history when the extent to which a significant portion of the population will adopt and amend these understandings of themselves will be clearer.

\section{Sexual Diversity: Counting Changing Concepts}

Estimates of the presence of individuals from sexual minorities in the overall population have been problematic. Methodological concerns about individuals' willingness to disclose stigmatised identities to the state or to research are reasonable in the context of identities that in sixty years, less than the average lifetime of a UK citizen, have gone from being illegal or pathological or both to being at least intermittently celebrated. ${ }^{14}$ The government could find no recent reliable estimate of LGBT numbers in the population in $2018 .{ }^{15}$ ONS experimental statistics indicate 2.3 per cent of the population are LGB, with many more young people identifying as such. ${ }^{16}$ As terminology changes and new categories achieve 
prominence, historical comparisons become harder. Older studies from the 1990s have generated range of figures, for example 5-12 per cent men and 3-5 per cent of women in the UK as gay, ${ }^{17} 5$ per cent of the UK population gay, lesbian or bisexual. ${ }^{18}$ Data on transgender are not collected as part of the annual population surveys, but the consultation on the Gender Recognition Act reported an estimate of between 200,000 and 500,000 and it is anticipated that the 2021 census will include a question on gender identity. ${ }^{19}$

The advent of civil partnerships (2004), legislation allowing same-sex couples essentially the same rights as heterosexual marriage, resulted in 53,415 couples (roughly equal numbers of men and women) using the legislation by 2011, five times the original government estimate. ${ }^{20}$ Only a small percentage (2.2 per cent for men and 4.6 per cent for women) of these partnerships are dissolved.

Family composition is varied in the UK. Official estimates suggest that in 2012 there were 18.2 million families of which 69,000 were same-sex cohabiting couples (of which 6,000 had dependent children) and 60,000 civil partnerships (of which 6,000 had dependent children). In 1996, prior to civil partnerships (and now gay marriage) there seemed to be far fewer, only 16,000 same-sex cohabiting couples (and 1,000 with dependent children). ${ }^{21}$ Gay couples have been able to adopt since 2002 and account for a rising percentage of adoptions. $^{22}$

\section{Legislation in the UK: From Crime to Weddings}

It is tempting to see the half-century of change, post-1960, in which this linguistic, conceptual and real-life journey has taken place, as moving inexorably in the direction of liberalisation, de-pathologisation and openness. In fact, it is more complex. ${ }^{23}$ Many legal changes took decades to materialise and were fought for every step of the way. Equally, there was a hardening of attitudes towards homosexuality in the 1980s. In 1987, only 11 per cent of the population thought same-sex relationships were 'not at all wrong', a figure that had changed to 47 per cent in 2012 and 64 per cent in $2016,{ }^{24}$ which allowed for the introduction of Section 28 in the Local Government Act. This effectively censored sex education in schools, arguably making it harder to counteract homophobic bullying and jeopardising the local groups supporting LBGT individuals in local communities by restricting the activities of local authorities. The extent to which statute law has changed is striking and indisputable. The sheer volume of legislation in this area, as opposed to legislation about women or those from black and minority ethnic groups, is remarkable (see Chapters 15 and 35).

\section{Key Legal Changes in the UK}

The journey encapsulated in Box 34.1 is not yet complete. Sexual practices among gay men have been decriminalised; hate crimes against the LGBT community are recognised; the inequality in the age of consent has been rectified; and the state recognises personal commitment between people of the same gender and allows someone to define their gender as they think fit (although this requires medical action). All areas of life have been affected by legal change so that inroads have been made to what happens in schools, workplaces and elsewhere.

It is also noticeable that the tone and vocabulary of government documents are very different; these have conspicuously adopted the self-defining terms used within the LGBT and wider community and in their very use speak to the depth of change since the Wolfenden Report. However, the debate about trans rights, for example, continues. 


\section{Box 34.1}

1957 Wolfenden Committee on Homosexuality and Prostitution

1967 Sexual Offences Act decriminalises consensual sexual acts between men over twentyone years of age in private (England and Wales)

1988 Local Government Act Section 28

1994 Legal recognition of male rape

2000 European Court of Human Rights (ECHR) challenge to law on gross indecency

2001 Equal age of consent regardless of sexual orientation

2002 Equality in the Mental Health Act with regard to 'nearest relative' (case law)

2003 Homophobic assault is recognised as a hate crime

2003 Repeal of Section 28 of the Local Government Act

2003 Repeal of Victorian laws on gross indecency and buggery

2004 Gender Recognition Act

2005 Civil Partnership Act (for same-sex couples only)

2010 Equality Act (creating a range of 'protected characteristics', including sexual orientation)

2013 Same-sex marriage (England, Wales and Scotland 2014; 2019 in Northern Ireland)

2017 'Turing's Law' in the Policing and Crime Act 2017 posthumously pardons men who were convicted for having sex with men prior to 1967 where the offence is no longer a crime

Aspects of this are acrimonious and unresolved at the time of writing, although the government has committed to further separate consultation with non-binary and intersex people. $^{25}$

\section{Psychiatry and Diagnostic Indecision}

Much of the thinking and many of the changes in the understanding and experience of sexual diversity since 1960 have occurred independent of psychiatry but the concepts within mental health and associated practices within mental health care have also been profoundly affected. Drescher has documented the evolution of diagnostic thinking within both the International Classification of Diseases (ICD) and the Diagnostic and Statistical Manual of Mental Disorders (DSM) over the second half of the twentieth century to the present day. ${ }^{26}$ As a gay psychiatrist who has lived and worked through many of the changes, it is a relief no longer to be a diagnosis. The self-belief of a profession which viewed the application of terms such as 'sexual deviation' or 'pathological personality' to gay individuals as reasonable jars with modern sensibilities. ${ }^{27}$ The individuals have not changed but the profession and the terminology certainly have.

In 1973, the American Psychiatric Association (APA) removed 'homosexuality' from DSM-II. This was done on a vote, a democratic approach rather than a scientific one, and based on a small constituency, few of whom were gay. ${ }^{28}$ ICD dragged its feet in comparison. In 1965, 'lesbianism' and 'sodomy' were added to the ICD-8 collection of sexual deviations already featuring homosexuality. ICD-9, in 1975, hedged its bets and, while 'homosexuality' was still a diagnosis, it was less clear that it was construed as a mental disorder. ${ }^{29}$ Not until 1992 did 'homosexuality' per se finally disappear, with ICD-10 featuring 'ego dystonic sexual orientation' instead. 'Gender identity disorder' appeared for the first time, having been in DSM since $1994 .^{30}$ 
The tension between wanting to help someone with a problem and pathologising them is evident in the history of psychiatry and all things LGBT. ${ }^{31}$ Access to health care can depend on having a diagnosis. While being a diagnosis resulted in gay men and women being sent to doctors (notably to psychiatrists) for help in what could and can be a hostile world, the sense of negative difference engendered by the diagnostic process is unavoidable. This is now being played out in the UK more markedly in relation to transgender individuals where the role of medicine in the current Gender Recognition Act is very clear and constrains a person's capacity for positive self-definition.

\section{Mental Health Problems and Sexual Minorities}

psychological and sociological research this century has almost always attempted to uncover sickness, psychological difficulty and unhappiness as intrinsic to homosexuality. Little heed is paid to the social context of the lives of gays and lesbians. ${ }^{32}$

It was not until 2003 that the first robust UK-based study was able to suggest that some mental health problems were more common in lesbian and gay individuals than in straight counterparts, ${ }^{33}$ echoing research done in north America. Gay men and lesbians had higher levels of psychological distress, greater exposure to recreational drugs and higher rates of self-harm and were more likely to have consulted mental health professionals as a result. These findings have persisted over time and now include similar information on bisexual, non-binary and transpeople. ${ }^{34}$

The uncoupling of distress from identity and the identification of an external set of societal stressors - for instance, LGBT hate crimes and bullying at school - is an important paradigm shift and echoed what gay people had been saying themselves. ${ }^{35}$ King and colleagues argued that both societal prejudice and restricted lifestyle opportunities contributed to their findings. ${ }^{36}$ Hunt and Minsky had earlier argued persuasively that, for the LGBT community, simply considering sexual orientation was inadequate and the intersectionalities with age, disability, youth issues and membership of a BAME community also mattered. ${ }^{37}$ The salience of this observation is evident in the later work that highlights the increased rates of mental health difficulties among LGBT young people, BAME individuals, disabled individuals and within lower-income households. ${ }^{38}$ Only with this more nuanced grasp of health needs and their origins can health services meet needs appropriately.

\section{Professional Practice with Sexual Minorities}

Medicine has an overt obligation to try and meet the health needs of the whole population without prejudice and LGBT people use health care like everybody else, perhaps more so. ${ }^{39}$ Unlike visible difference, LGBT status may not always be recognised by health care practitioners, regardless of their own sexual orientation or gender identity. There is substantial evidence that health services in general and mental health services in particular have historically failed to live up to the General Medical Council (GMC) standard. Patients perceived staff as holding negative views about their sexuality and connecting it with their mental health problems as well as responding negatively to self-disclosure by the patient. Bisexuals in particular reported negative experiences. ${ }^{40}$ In this context, a reluctance to be 'out' to health care professionals, an avoidance of health care and a wish to see LBGT clinical staff are understandable. 
Treatment issues have compounded this for LGB individuals and now in a related but also different way for transpeople. The history of the treatment of 'homosexuality' and its current manifestation as conversion or reparative therapy of LGBT people, endeavours which have involved mental health services but which are by no means confined to them, have caused pain and generated mistrust over much of the twentieth century. ${ }^{41}$ Psychodynamic theory and practice were often directed to changing sexual orientation in men and women, using a model of compulsory heterosexuality. ${ }^{42}$ With the same aim, behavioural theory and practice, ${ }^{43}$ for instance aversion therapy using electric shocks, was principally directed at gay men, sometimes those who had fallen foul of the courts. Individuals sought treatment mainly because of negative social or family attitudes towards their sexuality. More recently, there was further evidence, from a survey of 2,000 psychiatrists, psychologists and psychotherapists, that 4 per cent of these professionals were still prepared to offer treatment directed at altering sexual orientation from gay to straight where clients requested this and 17 per cent had done so previously. ${ }^{44}$ In 2018,5 per cent of a large sample of LGBT individuals had at some earlier point in their lives been offered reparative therapy and 2 per cent had undergone it (half within faith groups but one in five from health care professionals). ${ }^{45}$ A systematic review of psychological therapies in the UK and elsewhere found that early studies revealed that concern about LGBT identity precipitated contact with therapy but that was less true in recent studies. ${ }^{46}$ LGBT affirmative therapy was becoming ordinary and therapy was positively experienced unless an attempt to change sexual orientation was attempted.

A proportion of transpeople will seek help from primary care and specialist services for a number of aspects of their gender identity, including hormone treatment and surgery. Much recent material on transpeople's experience of care falls outside the historical scope of this chapter but suggests that specialist services are hard to access, transpeople will often avoid general health care and they often do not feel understood by health care services. ${ }^{47}$ Given the need for access to specialist services for a person's gender recognition, their long waiting times are unhelpful.

\section{UK Psychiatry and Sexual Minority Issues}

Sporadic work in the UK on attitudes in psychiatry to LGBT issues suggested that psychiatrists were influenced by disease models of sexual preference more than GPs. ${ }^{48}$ Bhugra and King found the opposite in a survey undertaken just before the AIDS crisis. ${ }^{49}$ Both these studies predate the removal of homosexuality form ICD-10. Current attitudes are uninvestigated. It is also far from clear how rigorous the approach is taken within either basic medical training or psychiatric training such that practitioners are culturally competent with LGBT patients. Without this information, it is debatable whether psychiatry knows enough about lifestyle, sexual practices and contemporary identity to provide an inclusive service for an LGBT patient; material from patients suggest that problems remain.

Against a background of political change, alterations to the diagnostic systems and anecdotal concern about homophobia against colleagues, support within the membership led the Royal College of Psychiatrists to endorse the formation of a Lesbian and Gay Special Interest Group (SIG) in 2001. In 2012, its remit expanded to include trans issues and it was renamed the Rainbow SIG. The original remit of this group was determined by the membership and was 'to promote discussion and research, provide expertise within the College and contribute to education'. ${ }^{50}$ Its regular appearance at mainstream College 
meetings and periodic workshops gave it a profile that allowed isolated psychiatrists to identify its activities and created the possibility of a broader audience for its work. It has provided a forum to discuss patient-focused issues - the broader social context of LGBT life, for example parenting, discrimination and intersectionality - in a clinical context, for instance by working with older LGBT people, and also to provide support to colleagues. Its advisory role within the College led to two position statements: one essentially in tandem with other mental health organisations on the lack of evidence for conversion therapy and another, more recently, on trans issues. ${ }^{51}$ This is in some contrast to the earlier work in the United States on diagnosis, perhaps because the College lacked a coherent LGBT voice until the formation of the SIG, long after many of the most difficult discussions on diagnostic entities had taken place. It may be that the NHS is better placed to transform organisations to provide inclusive environments for staff and patients. In 2020, only one mental health services Trust, Central and North West London (CNWL), is in the Stonewall Top 100 Employers list; no other NHS organisations are listed, suggesting that there is more to do; this is in line with recent evidence of experiences of care.

\section{Conclusion}

History, whether of psychiatry or not, does not have bookends. The focus of this contribution has necessarily been principally on the experiences of gays and lesbians in relation to psychiatry, as it was those issues that dominated the years from 1960 to 2010. Yet, as identities alter over time, there has been some space to acknowledge the mental health issues and experiences of those with a less well-rehearsed sense of self, for instance bisexual and transpeople, non-binary and intersex individuals whose voices have come to the fore only recently.

The historical period in question has been one of profound change, experienced as such by those of us affected by changing social attitudes, protection in the workplace and the street, public recognition of our relationships and stability for our children. Psychiatry, and UK psychiatry in particular, seems both central and peripheral: central because embedded in its previous way of thinking was a wholesale and widely shared sickness model of LGBT sexuality which has been overthrown; peripheral because it is hard to argue that psychiatry did anything more than follow where the emerging LGBT community and its influencers bravely led, backed up academically by a handful of social scientists, historians and psychologists. $^{52}$

Questions remain about the proper role of psychiatry going forward. Some may argue that this is a dismal history and in future there is no place for psychiatrists in relation to LGBT matters; but, as mental health services are used by many of the LGBT community, UK psychiatry can play a role, if it chooses to do so. However, if this chapter tells us anything, it is that psychiatry should adopt an unaccustomed humility that sits uneasily with the intrinsic power and authority of the profession.

\section{Key Summary Points}

- The sickness model of LGBT people was dominant within UK psychiatry and its impact was still apparent years later, despite the removal of homosexuality from ICD-10 in 1992.

- Conversion and reparative therapies were important aspects of psychiatrists' and other mental health practitioners' approaches to LGBT people, despite the lack of a credible evidence base. 
- More positive, gay-affirming therapeutic approaches have been developed and adopted by mental health practitioners, although many LGBT people report concerns about their experience of mental health care.

- Social changes (liberalisation in public attitudes and law) were brought about through complex social processes that owed nothing to UK psychiatry.

- The history of LGBT people in relation to psychiatry raises important questions about the legitimacy of psychiatric power and authority.

\section{Notes}

1. S. Nandy, The hijras of India: Cultural and individual dimensions of an institutionalised third gender role. In E. Blackwood, ed., The Many Faces of Homosexuality: Anthropological Approaches to Homosexual Behaviour, 35-54. London: Eurospan and Harrington, 1988; C. Callender and L. Kochems, Men and nomen: Male gender mixing statuses and homosexuality. In Blackwood, The Many Faces of Homosexuality, 165-78.

2. Hijras shake it! YouTube, 31 January 2014, www.youtube.com/watch?v=Vl2BOiBtRio; BBC News, Precolonial communities' history of gender fluidity. BBC News, 28 July 2020, www.bbc.co.uk/news/av/world53573764/pre-colonial-communities-history-of-gender-fluidity.

3. D. Souhami, The Trials of Radclyffe Hall. London: Weidenfeld and Nicholson, 1998.

4. BBC News, Germaine Greer: Transgender women are not women. BBC News, 24 October 2015, www .bbc.co.uk/news/av/uk-34625512/germaine-greer-transgender-women-are-not-women; J. K. Rowling, J. K. Rowling writes about her reasons for speaking out on sex and gender issues. J. K. Rowling website, 10 June 2020, www.jkrowling.com/opinions/j-k-rowling-writes-about-her-reasons-for-speaking-out-on-sex -and-gender-issues/.

5. J. Wolfenden, Report of the Committee on Homosexual Offences and Prostitution [Wolfenden Report]. London: Home Office Scottish Home Department, 1957, www.parliament.uk/about/living-heritage/trans formingsociety/private-lives/relationships/collections1/sexual-offences-act-1967/wolfenden-report-/.

6. J. Weeks, Coming Out: The Emergence of LGBT Identities in Britain from the Nineteenth Century to the Present (3rd ed.). London: Quartet, 2016.

7. See, for example, C. Allen, Homosexuality Its Nature Causes and Treatment. London: Staples Press, 1958.

8. E. Grinberg, How the Stonewall riots inspired today's Pride celebrations. CNN, 28 June 2019, https://edition .cnn.com/2019/06/28/us/1969-stonewall-riots-history/index.html.

9. A. Rich, Compulsory heterosexuality and lesbian existence. In A. Rich, Blood, Bread, and Poetry: Selected Prose, 1979-1985, 1986; A. Stewart-Park and J. Cassidy, We're Here: Conversations with Lesbian Women. London: Quartet; J. Dixon, Separatism: A look back at anger. In B. Cant and S. Hemmings, eds, Radical Records Thirty Years of Lesbian and Gay History, 69-84. London: Routledge, 1988.

10. T. Bereczky, Patient advocacy and the HIV community, BMJ Opinion (blog), 9 January 2017, https://blogs .bmj.com/bmj/2017/01/09/tamas-bereczky-patient-advocacy-and-the-hiv-community/.

11. C. Wolff, Bisexuality: A Study. London: Quartet, 1977.

12. J. Morris, Conundrum, London: Faber \& Faber, 1974; D. Souhami, No Modernism without Lesbians. London: Head of Zeus, 2020, pp. 111-212, Bryher.

13. See the Stonewall website: www.stonewall.org.uk; and the Mermaids website: https://mermaidsuk.org.uk.

14. E. Price, LGBT Sexualities in Social Care Research. London: School for Social Care Research, 2011, www .sscr.nihr.ac.uk/wp-content/uploads/SSCR-methods-review_MR002.pdf.

15. Government Equalities Office, National LGBT Survey: Summary Report. July 2018, https://assets .publishing.service.gov.uk/government/uploads/system/uploads/attachment_data/file/722314/GEO-LGBTSurvey-Report.pdf. 
16. Office for National Standards (ONS), Sexual Orientation, UK: 2018. Statistical Bulletin, 2020, www .ons.gov.uk/peoplepopulationandcommunity/culturalidentity/sexuality/bulletins/sexualidentityuk/2018.

17. K. Wellings, J. Field, A. Johnson et al., Sexual Behaviour in Britain. London: Penguin,1994.

18. A. M., Johnson, C. H., Mercer, B. Erens et al., Sexual behaviour in Britain: Partnerships, practices and HIV risk behaviours. Lancet (2001) 358: 1835-42.

19. Government Equalities Office, Reform of the Gender Recognition Act 2004 Consultation 2018. London: HMSO, 2018, https://assets.publishing.service.gov.uk/government/uploads/system/uploads/attachment_ data/file/721725/GRA-Consultation-document.pdf.

20. ONS, Civil Partnerships in the UK: 2012. Statistical Bulletin, 2013, www.ons.gov.uk/peoplepopulationand community/birthsdeathsandmarriages/marriagecohabitationandcivilpartnerships/bulletins/civilpartnership sinenglandandwales/2012-07-31.

21. ONS, Families and Households in the UK: 2012. Statistical Bulletin, 2013, www.ons.gov.uk/peoplepopulatio nandcommunity/birthsdeathsandmarriages/families/bulletins/familiesandhouseholds/2012-11-01.

22. Adoption Plus, www.adoptionplus.co.uk/LGBT-Gay-Adoption-UK.

23. Horsfall 1988.

24. National Centre for Social Research, Moral Issues: Sex, Gender Identity and Euthanasia. In British Social Attitudes, Vol. 34, www.bsa.natcen.ac.uk/media/39147/bsa34_moral_issues_final.pdf.

25. Government Equalities Office, Reform of the Gender Recognition Act 2004; Government Equalities Office, LGBT Action Plan: Improving the Lives of Lesbian, Gay, Bisexual and Transgender People. London: HMSO, 2018, https://assets.publishing.service.gov.uk/government/uploads/system/uploads/attachment_data/file/72 1367/GEO-LGBT-Action-Plan.pdf; J. Doward, Polarised' debate on gender recognition is harming UK, says equalities chief. The Guardian, 8 August 2020, www.theguardian.com/society/2020/aug/08/polarised-debateon-gender-recognition-is-harming-uk-says-equalities-chief.

26. J. Drescher, Queer diagnoses: Parallels and contrasts in the history of homosexuality, gender variance, and the Diagnostic and Statistical Manual. Archives of Sexual Behavior (2010) 39: 427-60, https://doi.org/10.1007 /s10508-009-9531-5; J. Drescher, Queer diagnoses revisited: The past and future of homosexuality and gender diagnoses in DSM and ICD, International Review of Psychiatry, 2015, 27: 386-95, https://doi.org/10.3109/0 9540261.2015.1053847.

27. World Health Organization (WHO), International Classification of Diseases and Related Health Problems (6th revision). Geneva: WHO,1948; WHO, International Classification of Diseases and Related Health Problems (7th revision). Geneva: WHO, 1955.

28. Drescher, Queer diagnoses.

29. WHO, International Classification of Diseases and Related Health Problems (8th revision). Geneva: WHO, 1965; WHO, International Classification of Diseases and Related Health Problems (9th revision). Geneva: WHO, 1975.

30. WHO, International Classification of Diseases and Related Health Problems (10th revision). Geneva: WHO, 1990.

31. M. King and A. Bartlett, British psychiatry and homosexuality. British Journal of Psychiatry (1999) 175: 106-13.

32. Ibid.

33. M. King, E. McKeown, J. Warner et al., Mental health and quality of life of gay men and lesbians in England and Wales: Controlled, cross-section study. British Journal of Psychiatry (2003) 183: 552-8.

34. M. Plöderl and P. Tremblay, Mental health of sexual minorities: A systematic review. International Review of Psychiatry (2015) 27: 367-85, https://doi.org/10.3109/09540261.2015.1083949; C. L. Bachmann and B. Gooch, LGBT in Britain: Health Report. London: Stonewall, 2018, www.stonewall.org.uk/system/files/lg bt_in_britain_health.pdf.

35. L. Trenchard and H. Warren, Something to Tell You: The Experiences and Needs of Young Lesbians and Gay Men in London. London: London Gay Teenage Group,1984. 
36. King, McKeown, Warner et al., Mental health and quality of life of gay men and lesbians.

37. R. Hunt and A. Minsky, Reducing Health Inequalities for Lesbian Gay and Bisexual People: Evidence of Health Care Needs, London: Stonewall, 2006, www.ilga-europe.org/sites/default/files/reducing_health_inequali ties_for_lesbian_gay_and_bisexual_people_evidence_of_health_care_needs.pdf.

38. Bachmann and Gooch, LGBT in Britain.

39. Good Medical Practice (GMC), Good Medical Practice. Guidance, March 2013, www.gmc-uk.org/-/media/ documents/good-medical-practice-english-20200128_pdf-51527435.pdf?la=en\&hash=DA1263358CCA88 F298785FE2BD7610EB4EE9A530.

40. E. McFarlane, Diagnosis: Homophobic. The Experiences of Lesbians, Gay Men and Bisexuals in Mental Health Services. London: PACE, 1997; J. Golding, Without Prejudice: Mind - Lesbian, Gay and Bisexual Mental Health Awareness Research. London: Mind, 1997; M. King and E. McKeown, Mental Health and Social Wellbeing of Gay Men, Lesbians and Bisexuals in England and Wales: A Summary of Findings. London: Mind, 2003, www.mindout.org.uk/wp-content/uploads/2012/06/SummaryfindingsofLGBreport.pdf.

41. King and Bartlett, British psychiatry and homosexuality; G. Smith, M. King and A. Bartlett, An oral history of treatments for homosexuality in Britain since the 1950s: I. The views of patients. British Medical Journal (2004) 328: 427-9; M. King, A. Bartlett and G. Smith An oral history of treatments for homosexuality in Britain since the 1950s: II. The views of professionals. British Medical Journal (2004) 328: 429-32.

42. A. Storr, Sexual Deviation. Harmondsworth, Penguin, 1965; M. Glasser, Homosexuality in adolescence. British Journal of Medical Psychology (1977) 50: 217-25; I. Rosen, Sexual Deviation. Oxford: Oxford University Press, 1996; J. MacDougall, Homosexuality in women. In J. Chasseguet-Smirgel, ed., Sexuality and New Psychoanalytic Views, 171-212. Ann Arbor: Michigan University Press; A. Bartlett, M. King and P. Phillips, Straight talking: An investigation of the attitudes and practice of psychoanalysts and psychotherapists in relation to gays and lesbians. British Journal of Psychiatry (2001) 179: 545-9; P. Phillips, A. Bartlett and M. King, Psychotherapists' approach to gay and lesbian patients/clients: A qualitative study. British Journal of Medical Psychology (2001) 74: 73-84.

43. M. J. McCulloch and M. P. Feldman, Aversion therapy in management of 43 homosexuals. British Medical Journal (1967) 2: 594-7; J. Bancroft, Aversion therapy of homosexuality: A pilot study of 10 cases. British Journal of Psychiatry (1969) 115: 1417-31.

44. A. Bartlett, G. Smith and M. King, The response of mental health professionals to clients seeking help to change or redirect same sex sexual orientation. BMC Psychiatry (2009) 9: 11, https://doi.org/10.1186/1471244X-9-11.

45. Wellings, Field, Johnson et al., Sexual Behaviour in Britain.

46. M. King, J. Semlyen, H. Killaspy et al., A Systematic Review of Research on Counselling and Psychotherapy for Lesbian, Gay, Bisexual \& Transgender People. London: British Association for Counselling and Psychotherapy, 2007, www.bacp.co.uk/media/1965/bacp-research-relating-to-counselling-lgbt-systematicreview.pdf.

47. S. Bridger, M. Snedden, C. L. Bachmann and B. Gooch, LGBT in Britain: Health Report. London: Stonewall, 2018, www.stonewallscotland.org.uk/sites/default/files/lgbt_in_scotland_-_health_report.pdf.

48. P. A. Morris, Doctors' attitudes to homosexuality. British Journal of Psychiatry (1973) 122: 435-6.

49. D. Bhugra and M. B. King, Controlled comparison of attitudes of psychiatrists, general practitioners, homosexual doctors and homosexual men to male homosexuality. Journal of the Royal Society of Medicine (1989) 82: 603-5.

50. Royal College of Psychiatrists, Annual Report to Council 2016. LGB Special Interest Group, www .rcpsych.ac.uk/docs/default-source/members/sigs/rainbow/rainbow-sig-annual-report-2016.pdf? sfvrsn=726ec7e3_4.

51. Royal College of Psychiatrists, Royal College of Psychiatrists' Statement on Sexual Orientation. Position Statement No. PS02/14, April 2014, www.rcpsych.ac.uk/docs/default-source/improving-care/better-mhpolicy/position-statements/ps02_2014.pdf?sfvrsn=b39bd77c_4; Royal College of Psychiatrists, Supporting Transgender and Gender-Diverse People. Position Statement No. PS02/18, March 2018, 
www.rcpsych.ac.uk/docs/default-source/improving-care/better-mh-policy/position-statements/ps02_18 .pdf?sfvrsn=af4d4aad_4.

52. See, for example, E. M. Ettore, Lesbians, Women and Society. London: Routledge and Kegan Paul, 1980; C. Wolff, Love between Women. London: 1971; K. Plummer, The Making of the Modern Homosexual. New York: Barnes \& Noble.1981; C. Kitzinger, The Social Construction of Lesbianism. London: SAGE, 1987. 